\title{
Rapid deployment aortic valves and minimally invasive aortic valve replacement: A perfect marriage of technology and technique?
}

\author{
Mattia Glauber, MD, Matteo Ferrarini, MD, and Antonio Miceli, MD, PhD
}

See related article on pages 434-40.

Since the first aortic valve replacement (AVR) through a right thoracotomy was reported in 1993, upper hemisternotomy and right anterior thoracotomy have become the predominant approaches for minimally invasive AVR (MIAVR). ${ }^{1,2}$ Clinical studies have documented comparable operative mortality, less bleeding, reduced pain, and shorter intensive care and hospital stays relative to conventional sternotomy. ${ }^{1,3-9}$ Accessing the aortic valve through a minimal access incision can be technically demanding, however, and longer procedural times are the rule. ${ }^{4}$ This may have significant clinical implications, because associations of major postoperative morbidity and mortality with prolonged procedural times have also been reported in the literature. ${ }^{10,11}$ Reducing the procedural times during MIAVR may therefore be of importance for improved postoperative clinical outcomes. Since the first implantation of sutureless aortic valves in the 1960s, recent technologic advances have made it possible to develop a new class of prosthetic heart valve substitutes, called rapid deployment aortic valves, which are intended to reduce procedure times and simplify conventional AVR operations. In the recent years, 3 different rapid deployment aortic valves have been introduced in Europe for use in both conventional AVR and MIAVR operations: the ENABLE Valve System (Medtronic, Inc, Minneapolis, Minn), the PERCEVAL S Valve System (Sorin Biomedica Cardio Srl, Sallugia, Italy), and the EDWARDS INTUITY Valve System (Edwards Lifesciences, Irvine, Calif). Favorable clinical outcomes with the use of these valves have been reported in several studies. ${ }^{12-14}$

In this issue of the Journal, Schlömicher and colleagues provide a perspective from a center experienced in MIAVR on the use of the EDWARDS INTUITY Valve System, which received European CE mark in February 2012. In this study, 60 patients underwent MIAVR with the

\footnotetext{
From the Cardiac Surgery and Great Vessels Department, Istituto Clinico Sant' Ambrogio, Gruppo Ospedaliero San Donato, Milan, Italy.

Disclosures: Author has nothing to disclose with regard to commercial support. Received for publication Oct 30, 2014; accepted for publication Oct 31, 2014.

Address for reprints: Mattia Glauber, MD, Cardiac Surgery and Great Vessels Department, Istituto Clinico Sant' Ambrogio, Gruppo Ospedaliero San Donato, Via Luigi Giuseppe Faravelli, 16, 20149 Milano, Italy (E-mail: mattia.glauber@gmail.com). J Thorac Cardiovasc Surg 2015;149:441-2

$0022-5223 / \$ 36.00$

Copyright (c) 2015 by The American Association for Thoracic Surgery http://dx.doi.org/10.1016/j.jtcvs.2014.10.123
}

EDWARDS INTUITY Valve System through an upper hemisternotomy approach. Mean age was 75.5 years, and mean $\log$ euroSCORE was 8.4. Technical success rate was $98.1 \%$. Mean crossclamp and cardiopulmonary bypass times were 26 minutes (range, 16-47 minutes) and 56 minutes, respectively. Importantly, the mean duration from first valve stitch to tying the final knot after valve deployment was only 9 minutes. Early and late valverelated mortalities were $1.7 \%$ and $3.4 \%$, respectively. No cases of late valve explantation, endocarditis, hemolysis, or structural valve deterioration were observed. At 1 year, valve hemodynamic performance was excellent, with an overall mean pressure gradient and a mean effective orifice area of $10.3 \mathrm{~mm} \mathrm{Hg}$ and $1.8 \mathrm{~cm}^{2}$, respectively. In particular, for the 21 -mm valve $(\mathrm{n}=17)$, mean gradient and effective orifice area were $10.2 \mathrm{~mm} \mathrm{Hg}$ and $1.5 \mathrm{~cm}^{2}$, respectively. Overall, the hemodynamic performance and safety outcomes observed at 1 year were favorable, with shorter procedural times and a high technical success rate, despite the added complexity of the minimally invasive approach. Rapid deployment aortic valve replacement through the use of the EDWARDS INTUITY Valve System has the potential to simplify MIAVR by reducing procedure times as the result of fewer sutures and faster implantation. ${ }^{15}$

Schlömicher and colleagues report 1 case $(1.7 \%)$ of moderate paravalvular leak (PVL) after weaning from cardiopulmonary bypass and no late PVL $(>1+)$ beyond the first 30 days. In the surgical AVR control arm of the Placement of Aortic Transcatheter Valves (PARTNER) trial, moderate or severe PVL rates were $1.9 \%$ at 1 year and $0.9 \%$ at 2 years. ${ }^{16}$ In the Surgical Treatment of Aortic Stenosis With a Next Generation Surgical Aortic Valve (TRITON) trial, ${ }^{17}$ in which the EDWARDS INTUITY Valve System was implanted in 287 patients through either a MIAVR or a full sternotomy approach, the rate of moderate or severe PVL was only $1.2 \%$ at 1 year. These results are similar to that of the study of Schlömicher and colleagues but are in contrast to the rates of major PVL observed with other rapid deployment AVR devices, which range between $6.7 \%$ and $19.4 \% .{ }^{17-24}$ Studies have correlated significant PVL with a higher risk of late mortality after transcatheter AVR, and the management of PVL by reoperation also carries a substantial risk. ${ }^{25}$ The EDWARDS INTUITY Valve System, either implanted through a conventional full sternotomy or minimally invasive approach, appears to be associated with rates of moderate or severe PVL equivalent to those of surgically implanted heart valves. This may be associated with 
improved late mortality and fewer reoperations relative to other rapid deployment AVR devices.

New permanent pacemaker implantation rates after surgical AVR and transcatheter aortic valve intervention have been reported to be between $3.0 \%$ and $8.5 \%$ and between $25.5 \%$ and $27.8 \%$, respectively. ${ }^{26-28}$ In the study of Schlömicher and colleagues, only 1 case of new permanent pacemaker implantation $(1.7 \%)$ was reported. This rate falls below the expected ranges for permanent pacemaker implantation after both surgical AVR and transcatheter aortic valve intervention and compares favorably with those seen with rapid deployment AVR devices other than the EDWARDS INTUITY Valve System, which have ranged between $7 \%$ and $17 \%$ in several studies. ${ }^{12,22,23,29}$

In conclusion, this early experience with the EDWARDS INTUITY Valve System demonstrates that short crossclamp and cardiopulmonary bypass times can be achieved with MIAVR. Further, excellent valve hemodynamic performance, with low rates of significant PVL and new permanent pacemaker implantation, can be expected. These data suggest that favorable clinical outcomes can be achieved despite the technically demanding nature of the minimally invasive approach. Certainly, I look forward to seeing these excellent clinical results replicated in other single-center and multicenter studies of MIAVR, with this device and also with other devices, and not only with a partial sternotomy approach but also through a right thoracotomy. If these results hold true, then the advent of rapid deployment aortic valves may indeed represent the perfect marriage between technology and technique.

\section{References}

1. Cosgrove DM III, Sabik JF. Minimally invasive approach for aortic valve operations. Ann Thorac Surg. 1996;62:596-7.

2. Rao PN, Kumar AS. Aortic valve replacement through right thoracotomy. Tex Heart Inst J. 1993;20:307-8.

3. Bonacchi M, Prifti E, Giunti G, Frati G, Sani G. Does ministernotomy improve postoperative outcome in aortic valve operation? A prospective randomized study. Ann Thorac Surg. 2002;73:460-5; discussion 465-6.

4. Brown ML, McKellar SH, Sundt TM, Schaff HV. Ministernotomy versus conventional sternotomy for aortic valve replacement: a systematic review and meta-analysis. J Thorac Cardiovasc Surg. 2009;137:670-9.e5.

5. Dogan S, Dzemali O, Wimmer-Greinecker G, Derra P, Doss M, Khan MF, et al. Minimally invasive versus conventional aortic valve replacement: a prospective randomized trial. J Heart Valve Dis. 2003;12:76-80.

6. Johnston DR, Atik FA, Rajeswaran J, Blackstone EH, Nowicki ER, Sabik JF III, et al. Outcomes of less invasive J-incision approach to aortic valve surgery. $J$ Thorac Cardiovasc Surg. 2012;144:852-8.e3.

7. Mächler HE, Bergmann P, Anelli-Monti M, Dacar D, Rehak P, Knez I, et al. Minimally invasive versus conventional aortic valve operations: a prospective study in 120 patients. Ann Thorac Surg. 1999;67:1001-5.

8. Murtuza B, Pepper JR, Stanbridge RD, Jones C, Rao C, Darzi A, et al. Minimal access aortic valve replacement: is it worth it? Ann Thorac Surg. 2008;85: 1121-31.

9. Raja SG, Navaratnarajah M. Impact of minimal access valve surgery on clinical outcomes: current best available evidence. J Card Surg. 2009;24:73-9.

10. Al-Sarraf N, Thalib L, Hughes A, Houlihan M, Tolan M, Young V, et al. Crossclamp time is an independent predictor of mortality and morbidity in low- and high-risk cardiac patients. Int J Surg. 2011;9:104-9.
11. Doenst T, Borger MA, Weisel RD, Yau TM, Maganti M, Rao V. Relation between aortic cross-clamp time and mortality — not as straightforward as expected. Eur J Cardiothorac Surg. 2008;33:660-5.

12. Folliguet TA, Laborde F, Zannis K, Ghorayeb G, Haverich A, Shrestha M. Sutureless Perceval aortic valve replacement: results of two European centers. Ann Thorac Surg. 2012;93:1483-8.

13. Kocher AA, Laufer G, Haverich A, Shrestha M, Walther T, Misfeld M, et al. One-year outcomes of the Surgical Treatment of Aortic Stenosis With a Next Generation Surgical Aortic Valve (TRITON) trial: a prospective multicenter study of rapid-deployment aortic valve replacement with the EDWARDS INTUITY Valve System. J Thorac Cardiovasc Surg. 2013;145:110-5; discussion 115-6.

14. Martens S, Sadowski J, Eckstein FS, Bartus K, Kapelak B, Sievers HH, et al. Clinical experience with the ATS $3 \mathrm{f}$ Enable ${ }^{\circledR}$ Sutureless Bioprosthesis. Eur J Cardiothorac Surg. 2011;40:749-55.

15. Wendt D, Thielmann M, Pizanis N, Jánosi RA, Kamler M, Jakob H. Sutureless aortic valves over the last 45 years. Minim Invasive Ther Allied Technol. 2009; 18:122-30.

16. Kodali SK, Williams MR, Smith CR, Svensson LG, Webb JG, Makkar RR, et al. Two-year outcomes after transcatheter or surgical aortic-valve replacement. $N$ Engl J Med. 2012;366:1686-95.

17. Haverich A, Wahlers TC, Borger MA, Shrestha M, Kocher AA, Walther T, et al. Three-year hemodynamic performance, left ventricular mass regression, and prosthetic-patient mismatch after rapid deployment aortic valve replacement in 287 patients. J Thorac Cardiovasc Surg. 2014;148:2854-61.

18. D’Onofrio A, Messina A, Lorusso R, Alfieri OR, Fusari M, Rubino P, et al. Sutureless aortic valve replacement as an alternative treatment for patients belonging to the "gray zone" between transcatheter aortic valve implantation and conventional surgery: a propensity-matched, multicenter analysis. $J$ Thorac Cardiovasc Surg. 2012;144:1010-6.

19. D’Onofrio A, Rizzoli G, Messina A, Alfieri O, Lorusso R, Salizzoni S, et al. Conventional surgery, sutureless valves, and transapical aortic valve replacement: what is the best option for patients with aortic valve stenosis? A multicenter, propensity-matched analysis. J Thorac Cardiovasc Surg. 2013;146:1065-70; discussion 1070-1.

20. Eichstaedt HC, Easo J, Härle T, Dapunt OE. Early single-center experience in sutureless aortic valve implantation in 120 patients. J Thorac Cardiovasc Surg. 2014; 147:370-5.

21. Flameng W, Herregods MC, Hermans H, Van der Mieren G, Vercalsteren M, Poortmans G, et al. Effect of sutureless implantation of the Perceval S aortic valve bioprosthesis on intraoperative and early postoperative outcomes. J Thorac Cardiovasc Surg. 2011;142:1453-7.

22. van Boxtel AGM, Houthuizen P, Hamad MAS, Sjatskig J, Tan E, Prinzen FW, Straten AHM. Postoperative conduction disorders after implantation of the self-expandable sutureless Perceval S bioprosthesis. J Heart Valve Dis. 2014; 23:319-24.

23. Rubino AS, Santarpino G, De Praetere H, Kasama K, Dalén M, Sartipy U, et al. Early and intermediate outcome after aortic valve replacement with a sutureless bioprosthesis: results of a multicenter study. J Thorac Cardiovasc Surg. 2014; 148:865-71; discussion 871.

24. Shrestha M, Folliguet T, Meuris B, Dibie A, Bara C, Herregods MC, et al. Sutureless Perceval S aortic valve replacement: a multicenter, prospective pilot trial. $J$ Heart Valve Dis. 2009;18:698-702.

25. Kliger C, Eiros R, Isasti G, Einhorn B, Jelnin V, Cohen H, et al. Review of surgical prosthetic paravalvular leaks: diagnosis and catheter-based closure. Eur Heart J. 2013;34:638-49.

26. Buellesfeld L, Stortecky S, Heg D, Hausen S, Mueller R, Wenaweser P, et al. Impact of permanent pacemaker implantation on clinical outcome among patients undergoing transcatheter aortic valve implantation. J Am Coll Cardiol. 2012;60:493-501

27. De Carlo M, Giannini C, Bedogni F, Klugmann S, Brambilla N, De Marco F, et al. Safety of a conservative strategy of permanent pacemaker implantation after transcatheter aortic CoreValve implantation. Am Heart J. 2012;163:492-9.

28. Nardi P, Pellegrino A, Scafuri A, Bellos K, De Propris S, Polisca P, et al. Permanent pacemaker implantation after isolated aortic valve replacement: incidence, risk factors and surgical technical aspects. J Cardiovasc Med (Hagerstown). 2010;11:14-9.

29. Baraki H, Al Ahmad A, Jeng-Singh S, Saito S, Schmitto JD, Fleischer B, et al. Pacemaker dependency after isolated aortic valve replacement: do conductance disorders recover over time? Interact Cardiovasc Thorac Surg. 2013;16:476-81. 